\title{
Interaction of thermal tolerance and oxygen availability in the eurythermal gastropods Littorina littorea and Nucella lapillus
}

\author{
John Davenport ${ }^{*}$, Julia L. Davenport \\ Department of Zoology, Ecology and Plant Science/Environmental Research Institute, University College Cork, \\ Distillery Fields, North Mall, Cork, Ireland
}

\begin{abstract}
Established hypothesis, derived predominantly from studies on wholly-aquatic polar organisms, indicates that the upper thermal limits of aquatic animals are defined by oxygen limitation. In this study Littorina littorea and Nucella lapillus, eurythermal temperate intertidal gastropods of different habit and life history, were investigated to test the generality of this hypothesis. Two separate hypotheses were tested on both species. Hypothesis 1 was that thermal tolerance in water will be increased under hyperoxic conditions and decreased under hypoxic conditions. Median upper lethal temperature/s (MULT) were established under normoxic $\left(21 \% \mathrm{O}_{2}\right)$, hypoxic $\left(10 \% \mathrm{O}_{2}\right)$ and hyperoxic $\left(40 \% \mathrm{O}_{2}\right)$ conditions in seawater. For Nucella lapillus the hypothesis was supported, since MULT increased with increasing available oxygen in seawater $\left(4.6^{\circ} \mathrm{C}\right.$ difference between hypoxic and hyperoxic conditions). For $L$. littorea the hypothesis failed, since MULT did not differ significantly between different oxic conditions. Hypothesis 2 was that thermal tolerance in water-saturated air (normoxia) would be higher than in normoxic water due to the greater availability of oxygen in air. MULT was established for both species in water-saturated air (it had already been established in normoxic seawater). For L. littorea this hypothesis was supported by data, as MULT was $2.4^{\circ} \mathrm{C}$ higher in air than in normoxic seawater. However, the hypothesis was rejected for N. lapillus, in which MULT in air was depressed by $1.6^{\circ} \mathrm{C}$ by comparison with MULT in normoxic seawater. The departures from oxygen limitation theory can be explained by the species' habits, life history and respiratory capabilities in air and water.
\end{abstract}

KEY WORDS: Thermal tolerance $\cdot$ Oxygen $\cdot$ Littorina $\cdot$ Nucella $\cdot$ Cleft

\section{INTRODUCTION}

Temperature is regarded as the most important abiotic stress affecting ectothermic animals, since it has influences from population to molecular levels (e.g. Hochachka \& Somero 2002). Relationships between environmental temperature and organismal distribution and temperature tolerance have been widely studied, especially as the impact of anthropogenicallydriven climate change has focused attention on thermal biology (e.g. Taschler \& Neuner 2004).

The seminal review of Pörtner (2001) demonstrates a close relationship between upper lethal temperature and the following attributes: an extended aerobic scope, the ability to switch to anaerobic metabolism and, in extremis, the ability to protect molecules by deployment of heat shock proteins and antioxidative defence. Pörtner (2001) postulated an intimate link between oxygen availability and critical temperatures for survival, and there is ample recent evidence to show that this relationship holds for polar invertebrates (e.g. Peck \& Conway 2000, Peck et al. 2002), for which thermal windows are very narrow.

From this body of work it may be hypothesized that enhanced oxygen availability should allow animals to survive to higher environmental temperatures and that reduced levels of environmental oxygen should reduce critical temperatures. In confirmation of this hypothe- 
sis, Pörtner et al. (2006) recently showed that doubling environmental oxygen tension raised upper thermal limits in the Antarctic bivalve Laternula elliptica by about $2.5^{\circ} \mathrm{C}$. However, this work was again performed on a stenothermal polar species. In the study reported here 2 temperate intertidal invertebrate species were investigated. Both target species are eurythermal gastropod molluscs (Clarke et al. 2000, Davenport \& Davenport 2005): the eulittoral (sensu McMahon 2001) herbivorous periwinkle Littorina littorea is distributed in Europe from northern Spain to the White Sea (northern Russia) (Jackson 2005); Nucella lapillus, a carnivore that occurs rather lower on the shore (lower eulittoral; sensu McMahon 2001), is found from the Straits of Gibraltar to the Arctic (Hayward \& Ryland 1995). Both species occupy a wide range of microhabitats on rocky shores. They can be found in rock pools that can fluctuate between considerably hyperoxic conditions during the day (when temperatures are usually high) and markedly hypoxic conditions at night (e.g. Ganning 1971, Daniel \& Boyden 1975, Morris \& Taylor 1983). They tolerate emersion, during which they may close themselves off from the environment if the humidity is low (by retraction of the foot and closure of the operculum), or they may continue to maintain full contact with the environment if conditions are damp. Although both species have gills, they are airbreathers when emersed. L. littorea has haemocyanin in the haemolymph (Herskovits et al. 1985), as does N. lapillus (Leung et al. 2000, Tyler-Walters 2003). Following McMahon (2001) it is probable that the middle shore L. littorea is a more competent air breather than the lower shore $N$. lapillus. However, the concentration of oxygen in air is much greater than in air-saturated seawater (though the oxygen tensions will be near identical; see Spicer \& Gaston (1999)), so a second hypothesis, that the gastropods should tolerate higher temperatures in air (even when evaporative cooling is not possible) than in air-saturated seawater, was also tested. Throughout our study we measured upper lethal temperatures ( $24 \mathrm{~h}$ exposure). These differ from the critical or pejus temperatures (sensu Pörtner 2001). Critical temperatures are those at which animals switch from aerobic to anaerobic mitochondrial metabolism and are then in a time/energy-limited tolerant state that cannot be sustained indefinitely. Thus acute upper lethal temperatures will be higher than critical temperatures, but the two values will converge the longer the period of high temperature exposure.

\section{MATERIALS AND METHODS}

Collection of species. Specimens of Nucella lapillus and Littorina littorea were collected from a single shore at Bullens Bay, Cork, Ireland $\left(51^{\circ} 38.584^{\prime} \mathrm{N}\right.$, $\left.8^{\circ} 33.052^{\prime} \mathrm{W}\right)$. For both species, animals were collected from the middle of their vertical distribution; Davenport \& Davenport (2005) have recently shown significant differences in thermal tolerances of $N$. lapillus taken from the upper and lower distributional limits, perhaps reflecting the highly localized genetic substructuring already demonstrated for the species (Kirby 2000).

Assessment of thermal tolerances. Thermal tolerances were assessed following Davenport \& Davenport (2005). For each target species, 20 freshly collected animals were exposed to each of a variety of temperature/oxygen level combinations, either in humid air or in seawater (34\%) (Table 1). Test temperatures (Table 2) were chosen pragmatically until at least 3 temperatures, which yielded mortality between 100 and $0 \%$, were identified for each temperature/oxygen level combination. For Nucella lapillus, test temperatures ranged between 19.7 and $32.5^{\circ} \mathrm{C}$; for Littorina littorea, the range was 31.8 to $38.9^{\circ} \mathrm{C}$. The larger number of test temperatures for $L$. littorea was required, because the species has particularly small temperature differences between low and high survival (Davenport $\&$ Davenport 2005). Several temperature baths (accurate to $\pm 0.1^{\circ} \mathrm{C}$ ) were used simultaneously, so that all upper lethal temperatures were measured within a $3 \mathrm{~d}$ period (22 August 2004 to 24 August 2004 for N. lapillus; 9 June 2005 to 11 June 2005 for L. littorea).

Animals were held in lidded plastic vessels appropriate to their size. If they were to be held in air, they

Table 1. Treatments used during assessments of median upper lethal temperatures (MULT). $\mathrm{RH}=$ relative humidity

\begin{tabular}{|c|c|c|}
\hline Expt & Treatment & Description \\
\hline 1 & Humid air & $\begin{array}{l}\text { normoxic: } 100 \% \text { RH: gas } \\
\text { content } 21 \% \text { oxygen, } \\
79 \% \text { nitrogen }\end{array}$ \\
\hline 2 & Normoxic seawater & $\begin{array}{l}\text { gas content } 21 \% \text { oxygen, } \\
79 \% \text { nitrogen }\end{array}$ \\
\hline 3 & Hypoxic seawater & $\begin{array}{l}\text { gas content } 10 \% \text { oxygen, } \\
90 \% \text { nitrogen }\end{array}$ \\
\hline 4 & Hyperoxic seawater & $\begin{array}{l}\text { gas content } 40 \% \text { oxygen, } \\
60 \% \text { nitrogen }\end{array}$ \\
\hline
\end{tabular}

Table 2. Temperatures used to assess thermal tolerances

\begin{tabular}{|ll|}
\hline Species & Temperature $\left({ }^{\circ} \mathrm{C}\right)$ \\
\hline Nucella lapillus & $19.7,26.2,28.6,29.6,30.3,30.6$, \\
& $31.4,32.5$ \\
& \\
Littorina littorea & $31.8,31.9,33.3,34.2,34.9,35.2$, \\
& $35.5,35.7,36.2,36.3,37.1,37.2$, \\
& $38.3,38.4,38.6,38.9$ \\
\hline
\end{tabular}


were kept together with water-saturated paper towelling to ensure $100 \%$ relative humidity (so that evaporative cooling was impossible: cf. McMahon 1990). If they were to be held in seawater, the lid was pierced so that a tube and air stone could be inserted into the seawater. The tube was connected either to a regulator supplying gas from a cylinder containing a mixture of oxygen and nitrogen (see Table 1 for details of gas mixtures used), or to an electrical aerator that pumped air through the seawater. Trials (using fibre-optic oxygen micro-sensors; PreSens) were carried out to confirm that the intended oxygen tension was attained within the test vessels when 20 animals were present. The vessels were placed in the temperature baths. Animals were exposed to temperatures for $24 \mathrm{~h}$, and then allowed to recover at ambient temperature for at least $2 \mathrm{~h}$ before assessment for mortality using binocular microscopes, forceps and needles to test for responsiveness. Median upper lethal temperatures (MULT) with asymmetrical 95\% CI were established for each of the conditions shown in Table 1 for each species using probit analysis (Finney 1971). Throughout this paper, significant differences between means $(p<0.05)$ are assumed if $95 \%$ CI do not overlap. An exposure period of $24 \mathrm{~h}$ was chosen, partly because no single duration of exposure is biologically relevant to animals that have a substantial vertical range on the shore (as do both dogwhelks and periwinkles). Pilot experiments showed that both study species could tolerate emersion in humid air for at least $2 \mathrm{~d}$.

\section{RESULTS}

The results obtained are summarized in Table 3 . It is evident that there was no commonality in response between the species. For Nucella lapillus held in seawater, MULT was significantly affected by oxygen tension/concentration, with MULT being higher the greater the amount of oxygen available. The 3 MULT values for hypoxic, normoxic and hyperoxic conditions were significantly different from each other. However, in humid air the MULT was significantly lower (by $1.6^{\circ} \mathrm{C}$ ) than in normoxic seawater, even though far more oxygen was available in air and the oxygen tensions were equal.

In contrast, for Littorina littorea held in seawater, MULT was unaffected by oxygen tension/concentration over the range tested (10 to $40 \%$ oxygen) with the 3 MULT values for hypoxic, normoxic and hyperoxic conditions being virtually identical. On the other hand, in humid air, periwinkles survived to a MULT significantly higher (by $2.4^{\circ} \mathrm{C}$ ) than they did in normoxic seawater.
Table 3. Median upper lethal temperatures (MULT) of dogwhelks Nucella lapillus and periwinkles Littorina littorea under different oxygen tensions/concentrations. LC/UC = lower and upper $95 \%$ confidence limits (CL) for MULT respectively

\begin{tabular}{|c|c|c|c|c|}
\hline Expt & Oxygen \% & $\operatorname{MULT}\left({ }^{\circ} \mathrm{C}\right)$ & $\mathrm{LC}\left({ }^{\circ} \mathrm{C}\right)$ & $\mathrm{UC}\left({ }^{\circ} \mathrm{C}\right)$ \\
\hline \multicolumn{5}{|c|}{ Nucella lapillus } \\
\hline 1 & 21 & 28.9 & 28.3 & 29.2 \\
\hline 2 & 10 & 26.4 & 25.9 & 26.9 \\
\hline 3 & 21 & 30.5 & 30.4 & 30.6 \\
\hline 4 & 40 & 31.0 & 30.8 & 31.2 \\
\hline \multicolumn{5}{|c|}{ Littorina littorea } \\
\hline 1 & 21 & 37.5 & 37.2 & 37.9 \\
\hline 2 & 10 & 35.1 & 34.8 & 35.4 \\
\hline 3 & 21 & 35.1 & 34.9 & 35.3 \\
\hline 4 & 40 & 35.0 & 34.8 & 35.3 \\
\hline
\end{tabular}

\section{DISCUSSION}

MULT (24 h) temperatures of Littorina littorea in seawater clustered around $35^{\circ} \mathrm{C}$. No values for critical/ pejus temperature (sensu Pörtner 2001) for the species are available, though Clarke et al. (2000) published heat coma temperatures (HCT) for geographically separated populations of the species; these were derived from experiments in which animals were warmed at $0.2^{\circ} \mathrm{C} \mathrm{min}^{-1}$. HCT and critical temperatures are believed to be similar. HCT values for $L$. littorea given by Clarke et al. (2000) clustered around $30^{\circ} \mathrm{C}$, confirming that MULT values exceed critical temperatures but also implying that survival beyond critical temperatures is possible for many hours in this species. No such comparisons are possible for Nucella lapillus.

The results presented here demonstrate that oxygen availability and upper lethal temperature are not necessarily closely coupled in eurythermal temperate gastropods as they are in stenothermal polar molluscs (Peck et al. 2004, Pörtner et al. 2006). While the slow moving, low activity (Hughes et al. 1992) dog whelk Nucella lapillus does show such coupling in that there was a $4.6^{\circ} \mathrm{C}$ difference between MULT in hypoxic and hyperoxic conditions (in seawater), the highly mobile, active browser Littorina littorea showed no such difference. The 2 species also differ in their thermal tolerance pattern when in water-saturated air. $N$. lapillus tolerated a significantly lower MULT (by about $1.6^{\circ} \mathrm{C}$ ) in air than in air-saturated seawater, but $L$. littorea survived to a MULT $2.4^{\circ} \mathrm{C}$ higher when in air than in air-saturated seawater. Tomanek \& Helmuth (2002) point out that the relationship between intertidal distribution and ecophysiology of rocky intertidal organisms is extremely complex and that simple models are inadequate to encompass all species; our study reinforces this view.

Can the data be explained in the context of the Pörtner (2001) synthesis? We believe that they can to some ex- 
tent, if the different physiological characteristics of the 2 species are taken into account. Nucella lapillus is of the group of lower shore gastropods that is predicted to have a limited ability to take up oxygen from air (McMahon 2001), so this may explain why dogwhelks cannot survive to higher temperatures in humid air than in airsaturated seawater. At high temperature they will exceed aerobic scope, even though plenty of oxygen is present in the surrounding medium. Conversely, Littorina littorea is a competent air breather that can take advantage of the ready availability of oxygen in air to maintain aerobic scope to a higher temperature than in seawater.

When in seawater the thermal tolerance of Littorina littorea was unaffected over the hypoxic-hyperoxic range tested (unlike Nucella lapillus). This presumably reflects an efficient haemolymph circulation (Andrews \& Taylor 1988) and haemolymph-haemocyanin carriage of oxygen to the tissues. It should be noted that in the experimental conditions used in this study, the seawater was always in motion because of aeration by the test gas mixtures. Irwin \& Davenport (2006) have recently demonstrated that $L$. littorea cannot disperse unstirred layers by its gill ciliary activity, so that hypoxic conditions prevail around its tissues if it is held in static normoxic seawater. It is therefore likely that the species is more susceptible to high temperature when in unstirred rock pools/ puddles than in situations where wind or wave-driven circulation disperses unstirred layers.

Acknowledgements. This work was partly funded by the Irish Marine Institute under the Marine RTDI Measure: Postdoctoral Fellowship Award 2001/2002 (Ref: PDOC/01/006) 'Monitoring and predicting the influence of climate change on the marine flora and fauna of the islands of Great Britain and Ireland using intertidal indicators'.

\section{LITERATURE CITED}

Andrews EB, Taylor PM (1988) Fine structure, mechanism of heart function and haemodynamics in the prosobranch gastropod mollusc, Littorina littorea (L.). J Comp Physiol B 158: $247-262$

Clarke AP, Mill PJ, Grahame J, McMahon RF (2000) Geographical variation in heat coma temperatures in Littorina species (Mollusca: Gastropoda). J Mar Biol Assoc UK 80:855-863

Daniel MJ, Boyden CR (1975) Diurnal variation in physicochemical conditions within intertidal rockpools. Field Stud 4:161-176

Davenport J, Davenport JL (2005) Effects of shore height, wave exposure and geographical distance on thermal niche width of intertidal fauna. Mar Ecol Prog Ser 292:41-50

Finney DJ (1971) Probit analysis, 3rd edn. Cambridge University Press, Cambridge

Ganning B (1971) Studies on chemical, physical and biological conditions in Swedish rockpool ecosystems. Ophelia 2: 51-105

Haywood PJ, Ryland JS (1995) Handbook of the marine fauna of north-west Europe. Oxford University Press, Oxford

Editorial responsibility: Howard Browman (Associate Editorin-Chief), Storebø, Norway
Herskovits TT, Mazzella LJ, Villanueva GB (1985) Lightscattering investigation of the dissociation behavior of Lunatia heros and Littorina littorea hemocyanins. Biochemistry 16:3862-3870

Hochachka PW, Somero GN (2002) Biochemical adaptation: mechanism and process in physiological evolution. Oxford University Press, New York

Hughes RN, Burrows MT, Rogers SEB (1992) Ontogenic changes in foraging behaviour of the dogwhelk Nucella lapillus (L.). J Exp Mar Biol Ecol 155:199-212

Irwin S, Davenport J (2006) Implications of water flow and oxygen gradients for molluscan oxygen uptake and respirometric measurements. J Mar Biol Assoc UK 86:401-402

Jackson A (2005) Littorina littorea. Common periwinkle. Marine life information network: biology and sensitivity key information sub-programme. Plymouth: Mar Biol Assoc UK (available at: http://www.marlin.ac.uk/species/Littorinalittorea.htm)

Kirby RR (2000) An ancient transpecific polymorphism shows extreme divergence in a multitrait cline in an intertidal snail (Nucella lapillus (L.)). Mol Biol Evol 17:1816-1825

Leung KMY, Taylor AC, Furness RW (2000) Temperaturedependent physiological responses of the dogwhelk Nucella lapillus to cadmium exposure. J Mar Biol Assoc UK 80: 647-660

McMahon RF (1990) Thermal tolerance, evaporative water loss, air-oxygen consumption and zonation of intertidal prosobranchs: a new synthesis. Hydrobiologia 193:241-260

McMahon RF (2001) Acute thermal tolerance in intertidal gastropods relative to latitude, superfamily, zonation and habitat with special emphasis on the Littorinoidea. J Shellfish Res 20:459-467

Morris S, Taylor AC (1983) Diurnal and seasonal variation in physico-chemical conditions within intertidal rock pools. Estuar Coast Shelf Sci 17:339-355

Peck LS, Conway LZ (2000) The myth of metabolic cold adaptation: oxygen consumption in stenothermal Antarctic bivalves. In: Harper E, Taylor JD, Crame JA (eds) Evolutionary biology of the Bivalvia. (Spec Publ 177) Geological Society, London, p 441-450

Peck LS, Pörtner HO, Hardewig I (2002) Metabolic demand, oxygen supply and critical temperature in the Antarctic bivalve Laternula elliptica. Physiol Biochem Zool 75: 123-133

Peck LS, Webb KE, Bailey DM (2004) Extreme sensitivity of biological function to temperature in Antarctic marine species. Funct Ecol 18:625-630

Pörtner HO (2001) Climate change and temperature-dependent biogeography: oxygen limitation of thermal tolerance in animals. Naturwissenschaften 88:137-146

Pörtner HO, Peck LS, Hirse T (2006) Hyperoxia alleviates thermal stress in the Antarctic bivalve Laternula elliptica: evidence for oxygen limited thermal tolerance. Polar Biol DOI 10.1007/s00300-005-0106-1

Spicer JI, Gaston KJ (1999) Amphipod gigantism dictated by oxygen availability. Ecol Lett 2:397-403

Taschler D, Neuner G (2004) Summer frost resistance and freezing patterns measured in situ in leaves of major alpine plant growth forms in relation to their upper distribution boundary. Plant Cell Environ 27:737-746

Tomanek L, Helmuth B (2002) Physiological ecology of rocky intertidal organisms: a synergy of concepts. Integr Comp Biol 42:771-775

Tyler-Walters H (2003) Nucella lapillus. Dog whelk. Marine life information network: biology and sensitivity key information sub-programme. Plymouth: Mar Biol Assoc UK. (available at: http://www.marlin.ac.uk/species/Nucellalapillus.htm).

Submitted: May 4, 2006; Accepted: July 13, 2006

Proofs received from author(s): January 24, 2007 